\title{
Aegilops Species for the Improvement of the Leaf and Stripe Rust Resistance in Cultivated Triticale (xTriticosecale Wittmack)
}

\author{
Waldemar Ulaszewski ${ }^{1}$ (D) and Michał Tomasz Kwiatek ${ }^{2, *(D)}$ \\ 1 Institute of Plant Genetics of the Polish Academy of Sciences, Strzeszyńska 34 str., 60-479 Poznań, Poland; \\ wula@igr.poznan.pl \\ 2 Department of Genetics and Plant Breeding, Poznań University of Life Sciences, Dojazd 11, \\ 60-637 Poznań, Poland \\ * Correspondence: michal.kwiatek@up.poznan.pl; Tel.: +48-6184-87-760
}

Received: 26 October 2020; Accepted: 16 December 2020; Published: 18 December 2020

\begin{abstract}
Hexaploid triticale ( $\times$ Triticosecale Wittmack, $2 n=6 x=42$ chromosomes, AABBRR) is a cultivated hybrid, which combines wheat (Triticum aestivum L.) and rye (Secale cereale L.) properties. It has a better ability to be grown on poor soils, compared to wheat. Mainly, triticale is produced for forage feed and bioethanol. Considering the limited diversity of this human-made crop, there is a need to widen its genetic variability, especially to introduce new genes, responsible for agronomic traits, such as resistance to biotic stresses. Leaf rust caused by Puccinia triticina Eriks. and stripe rust caused by Puccinia striiformis Westend are the most destructive foliar diseases of triticale and related cereals. Developing resistant triticale varieties is an important strategy for the control of these diseases. A number of leaf and stripe rust resistance genes have been already introduced into bread wheat from related species using chromosome manipulations. Exploitation of related species conferring desirable loci is the most effective non-GMO way of improving the rust resistance of triticale. The procedure encompasses chromosome doubling of obtained hybrids followed by a number of backcrosses to eliminate unnecessary alien chromatin and to reduce the linkage drag. In this review, we show the recent status of pre-breeding studies, which are focused on transfer of leaf and stripe rust resistance genes from Aegilops species into cultivated triticale using distant crossing and chromosome engineering.
\end{abstract}

Keywords: Aegilops; triticale; leaf rust; stripe rust; yellow rust; resistance; Puccinia

\section{Introduction}

The hexaploid triticale ( $\times$ Triticosecale Wittmack, $2 n=6 x=42$, AABBRR), a small grain cereal, is a man-made crop developed by crossing Triticum species as a female parent and rye (Secale cereale $\mathrm{L}$.) as a male parent. In principle, triticale was intended to combine the nutritional value of the wheat and the rapid growth, cold tolerance, and hardiness of rye. Cultivated hexaploid triticale exhibits amphiploidy with respect to wheat (AABB) and rye (RR) genomes. Triticale is one of few artificial crops cultivated at a large scale. In general for the last decades the global harvested area of triticale has been constantly increasing $(2,101,405$ ha in $1996 ; 3,662,363$ ha in 2006; and 3,809,192 ha in 2018) [1]. The major importance of this cereal is based on the protein content in seeds. It may vary from 12 to $22 \%$. Feeding experiments involving farm animals have shown that triticale seem to be more digestible in comparison with parental species [2]. The primary end-use of triticale is forage production. However, growing demand for food resources and biofuel has led to an increased interest in development of this cereal. The end-use of triticale depends of the characteristics of its cultivar and is largely determined by its chemical composition. Cultivars of large and uniform grains containing more 
proteins than starch are used as concentrated feed for poultry, ruminants, and monogastrics. Cultivars forming high amount of biomass, like rye, are grazed or harvested for silage, green-feed, and hay [2,3]. At first triticale has mostly been used as animal feed, and its potential still has not been fully utilized at a large scale. Recently this crop has found application in food industry, including baking [4] and brewing [5]. Triticale has also been used as a substrate for bioethanol and biofuel production [6].

The genetic variability of triticale is limited due to lack of natural speciation, narrow genepool of parental forms (wheat and rye) and development of new breeding techniques, which induce high homozyosity (i.e., double haploid production) [7]. The first attempt to obtain triticale was completed by Wilhelm Rimpau in Germany in 1888 by crossing hexaploid wheat and rye and inducing spontaneous chromosome doubling of the sterile hybrid that is produced using conventional plant breeding hybridizing techniques between wheat and rye [8]. In the 1950s Arpad Kiss discovered that hexaploid forms of triticale would be more agronomically appropriate than its octoploid forms [9]. The same researcher coined the terms "Secondary Hexaploid Triticale" (SHT) and "Primary Hexaploid Triticale" (PHT) to distinguish lines derived from different combination of crosses [8]. PHT encompasses hexaploid lines of triticale obtained by crossing $6 \times$ triticale with $6 \times$ triticale where $\mathrm{A}$ and $\mathrm{B}$ genomes derive from tetraploid wheat. SHT encompasses hexaploid lines of triticale obtained by crossing $8 \times$ triticale with $6 \times$ triticale where A and B genomes are recombined from tetraploid and hexaploid wheat [7]. The first commercial cultivars of hexaploid triticale came onto the market in the late 1960s as T-No.57 and T-No.6 [9]. This cereal was as competitive as rye on marginal soils but contained $30-50 \%$ more protein. In May 1969 triticale became recognized as a new crop of commerce in Canada with the licensing of the hexaploid triticale cv Rosner [10]. The properties of triticale has motivated breeders to include triticale in their cereal breeding program. In Poland, which is now the biggest producers of triticale modern breeding and research of this crop started in 1960s. In 1982 the variety "Lasko", representing a favorable combination of yield potential, was the first cultivar of triticale registered in Poland and played a significant role in popularization of this new crop in Europe [11]. Currently, triticale breeding programs are aimed at the selection of highly yielding population varieties with increased resistance to fungal diseases (especially to leaf and stripe rust) [12].

\section{Current Status of Triticale Resistance against Leaf and Stripe Rusts}

Until the breakdown of resistance, triticale had not been prone to harmful effects of various pathogens. Currently, this cereal meets pathogens and pests deriving both from wheat and rye. The first triticale disease which occurred in epidemic proportions was stem rust (Pucinia graminis f.sp. tritici) in Australia [2]. Then, leaf rust (syn. brown rust, caused by Puccinia triticiana Eriks) and stripe rusts (syn. yellow rust, caused by P. striiformis f.sp. tritici) began to affect this crop everywhere it grows. As triticale started to expand into new production areas, new hybrid pathotypes of Puccinia, carrying virulence genes have evolved and broadened their range of hosts, moving from wheat and rye into triticale [13]. Both leaf and stripe rust are able to cause economic losses and decrease the grain yield even by $40 \%$ [2]. There is an urgent need to overcome this problem and enhance the resistance to these diseases.

The rust fungi (Pucciniales) (previously known as Uredinales) are the obligate, biotrophic basidiomycete fungal plant pathogens, infecting the representants of all vascular plant groups. The rust fungi are one of the most devastating threats to agricultural crops worldwide [14]. They are typified by the orange-brown-red rust color of one or more spore stages. Many aspects of biology of Pucciniales remain unclear. The research on these fungi is complicated due to their absolute dependence on the host and thus lack of possibility to culture them on artificial media [15]. In natural environment of Puccinia triticina and P. striiformis, individual populations of these fungi include many physiological races (pathotypes) with different levels of virulence. The airborne nature of these rust fungi as well as their tendency to increase its genetic variability by mutations and selection are factors allowing the pathogenic fungus to develop virulence against different cultivars carrying one or more resistance $(R)$ genes against the most prevalent races of $P$. triticina and $P$. striiformis in a given region. Some estimates suggests that resistance against a specific rust resistance gene does not last more than $5-7$ years; 
therefore, an introgression of new and effective resistance genes is a regular activity in breeding programs of cereals [16].

There are over 70 leaf rust and stripe rust resistance genes, securing either race-specific resistance or non-race specific adult-plant resistance (APR), that have been identified in Triticae [17] and some of them have already been transferred from related species into the wheat genetic background [18]. Each of these genes confers excellent resistance to some pathotypes, but none of them can be expected to work against all pathotypes. The secondary gene pools as a source of effective leaf rust $(L r)$ resistance and stripe rust $(Y r)$ resistance genes for triticale are wild relatives of wheat such as Aegilops, Thinopyrum, and Triticum species [18]. There are, in general, three categories of rust resistance in plants: race-specific seedling resistance, also known as all-stage resistance; race-specific adult plant resistance (race-specific APR); and race non-specific APR, also known as slow-rusting or partial resistance [16]. Particular races of rust fungi are specialized in different cereal host species. For example, P. triticina is able to successfully infect different small grain cereal species. Puccinia triticina f.sp. tritici is specialized in wheat [16]. P. triticina f.sp. secalis attacks rye [19]. Triticale is usually resistant to leaf rust of rye. The isolates of leaf rust from triticale in the field are usually wheat leaf rust [2]. Potentially, there is a possibility of somatic hybridization of rust fungi, which originally lived on wheat and rye and have moved into triticale. Evidences provided by Park and Wellings [20] suggest that some pathotypes of $P$. triticina may have arisen from somatic hybridization of different strains. It has been already confirmed that phylogenetically related fungal pathogen strains of triticale deriving from wheat and triticale, separately, have fused and adapted to live in new host plants [2].

Both hexaploid triticale and hexaploid wheat possess A and B genomes. The difference is that wheat has the additional $\mathrm{D}$ genome and triticale has the $\mathrm{R}$ genome instead. It is known that the presence of genes located on the chromosomes from D-genome downregulates the expression of leaf and stem rust resistance genes [21]. Potential of triticale as a crop lies in its ability to withstand several environmental stresses more effective than wheat. Moreover, the resistance of triticale to common wheat diseases is higher [22]. The newly formed triticale had been resistant to most of pathogens attacking wheat and rye until the breakdown of this resistance. Triticale as a hybrid plant has inherited leaf and stripe rust resistance from both progenitor species. The leaf rust isolated from triticale in the field is usually wheat leaf rust $P$. triticina [2]. Triticale is usually resistant to leaf and yellow rust of rye (P. tritici f.sp. secalis), and is a source of $L r 25, L r 26, L r 45, Y r 9$, and $Y r 83$ effective genes [23,24].

There is relatively small number of reports on Puccinia striiformis f.sp. tritici, the causal agent of yellow rust. However, recently this pathogen in cereals becomes a production problem worldwide. However, the new triticale yellow rust pathotype, called "Jackie $143 \mathrm{E} 16 \mathrm{~A}+\mathrm{J}+$ " has appeared in 2007. It is virulent for the gene $Y r 9$, a stripe rust resistance gene derived from cereal rye, common in most triticale varieties [24].

In general, hexaploid and octoploid triticales were initially resistant or moderately resistant to leaf rust [12]. The resistance however started to be broke down by new races of Puccinia. Tyryshkin et al. [25] selected only 24 highly resistant, at the seedling stage, accessions out of 471 tested. Mikhailova et al. [26] tested 416 triticale accessions and found only 17 leaf rust resistant triticale accessions. Manninger [27] tested the resistance of eight winter triticale accessions to leaf rust at seedling and adult stage. Cultivars Presto, Tricolor, Disco, GK Bogo, Kitaro, and Pongo were proven resistant at the seedling stage to three pathotypes of wheat leaf rust and susceptible only to one pathotype. Only two cultivars Presto and Tricolor have been proved to be resistant to leaf rust at adult stage. Manninger tested also resistance of wheat to leaf rust. Most pathotypes identified were virulent to resistant genes ( $L r 2 b, L r 2 c, L r 3, L r 11, L r 17, L r 21$, and $L r 26)$. Pathotypes from triticale were virulent only to $L r 2 b, L r 2 c$, and Lr11. Czajkowski et al. [28] conducted an analysis of susceptibility of 250 lines of winter triticale to $P$. triticina in the $2007 / 2008$ and 2012/2013 growing seasons. They showed that at a seedling stage $28 \%$ of examined genotypes were slightly affected by pathogen deriving from triticale and $83.2 \%$ by fungus isolated from wheat. It may indicate that the pathogen has specialized against specific sets of $L r$ genes. Adult stage analyses after manual inoculation showed that $56.8 \%$ of triticale forms were slightly 
affected by pathogen, whereas only $4.8 \%$ were strongly and $38.4 \%$ moderately affected. Analysis of susceptibility of triticale in the natural inoculation conditions showed that slightly affected genotypes turned to be predominant $(79.2 \%)$. Only $3.2 \%$ of genotypes were strongly and $17.6 \%$ moderately affected. Grzesik and Strzembicka [29], in order to determine identity of genes taking part in resistance of triticale against leaf rust, crossed resistant cultivars: Presto, Ugo, and Vero in all combinations. The greenhouse and field inoculation trials of F1 and F2 showed that all plants were resistant against 65a/95 P. triticina strain, similarly as parental forms. Results of this experiment indicate that this resistance is determined by $L r$ genes of the same mechanism of action. Presto and Vero cultivars are similar and derive from Hungarian material developed by Kiss basing on the Triticum turgidum plasma and American developed by Jenkins and basing on Triticum durum plasma. Ugo cultivar has also T. durum plasma-deriving material in its ancestry. The resistance of many T. durum bases on the Lr23 gene and in some cases also Lr3, Lr10 and Lr13. Previous study of Grzesik and Strzembicka [30] revealed that resistance of triticale to Puccinia recondita (Eriks. \& E.Henn.) D.M.Henderson 65a/95 strain in the seedling stage in Presto and Ugo cultivars is determined by two leaf rust resistance genes and in Vero cultivar by one dominant $L r$ gene. In the adult stage the resistance was determined by $1-3 L r$ genes. The interaction between Puccinia and triticale is very dynamic. Species of pathogenic rust fungi deriving from both wheat and rye hosts are able to evolve by favorable single-step mutations within their genomes or somatic hybridization, acquiring new characteristics [2]. Therefore, resistance to leaf and stripe rust, in the present day, needs to be enhanced. The most economic, and environmentally friendly, safe and effective way to control the disease and to minimize losses is growing resistant cultivars. Wild relatives of wheat and triticale have been used as a secondary gene pool and source of leaf and stripe rust resistance genes.

\section{The Use of Aegilops Species for Improvement Leaf and Stripe Rust Resistance in Hexaploid Triticale}

High genetic variability of Aegilops species makes them valuable secondary gene pool for wheat and triticale to improve. There is a number of $L r$ and $Y r$ genes identified in Aegilops species [17]. Many of them have already been introduced into wheat and some into triticale [31-33] (Table 1). Kwiatek et al. [34] initiated a scientific project, which aimed to transfer of chromosome segments of wild goatgrasses (Aegilops sp.) carrying genes responsible for resistance against fungal diseases into triticale. The intermediate step of introducing desirable genes from Aegilops into triticale genome was to develop amphiploid lines between triticale and certain Aegilops ssp. carrying desirable trait [7]. Considering that additional genome/s may negatively impact on the hybrid development and decrease the crop yield, subsequent backcrossing were performed in order to reduce the genetic linkage-drag (Figure 1).

Table 1. Leaf and stripe rust resistance genes transferred from Aegilops species into triticale genome through distant hybridization followed by back-crossing.

\begin{tabular}{ccc}
\hline Species & Resistance Genes (Chromosomal Location) & References \\
\hline \multirow{2}{*}{ Ae. tauschii } & $\operatorname{Lr} 22 a(2 \mathrm{DS})$ & {$[31,33]$} \\
& $\operatorname{Lr32}(3 \mathrm{D})$ & {$[31]$} \\
& $\operatorname{Lr39}(2 \mathrm{DS})$ & {$[31,33]$} \\
\hline \multirow{2}{*}{ Ae. kotschyi Boiss. } & $\operatorname{Lr} 54\left(2 \mathrm{~S}^{\mathrm{k}} \mathrm{L}\right)$ & {$[32,34]$} \\
& $Y r 37\left(2 \mathrm{~S}^{\mathrm{k}} \mathrm{L}\right)$ & {$[32,34]$} \\
\hline
\end{tabular}



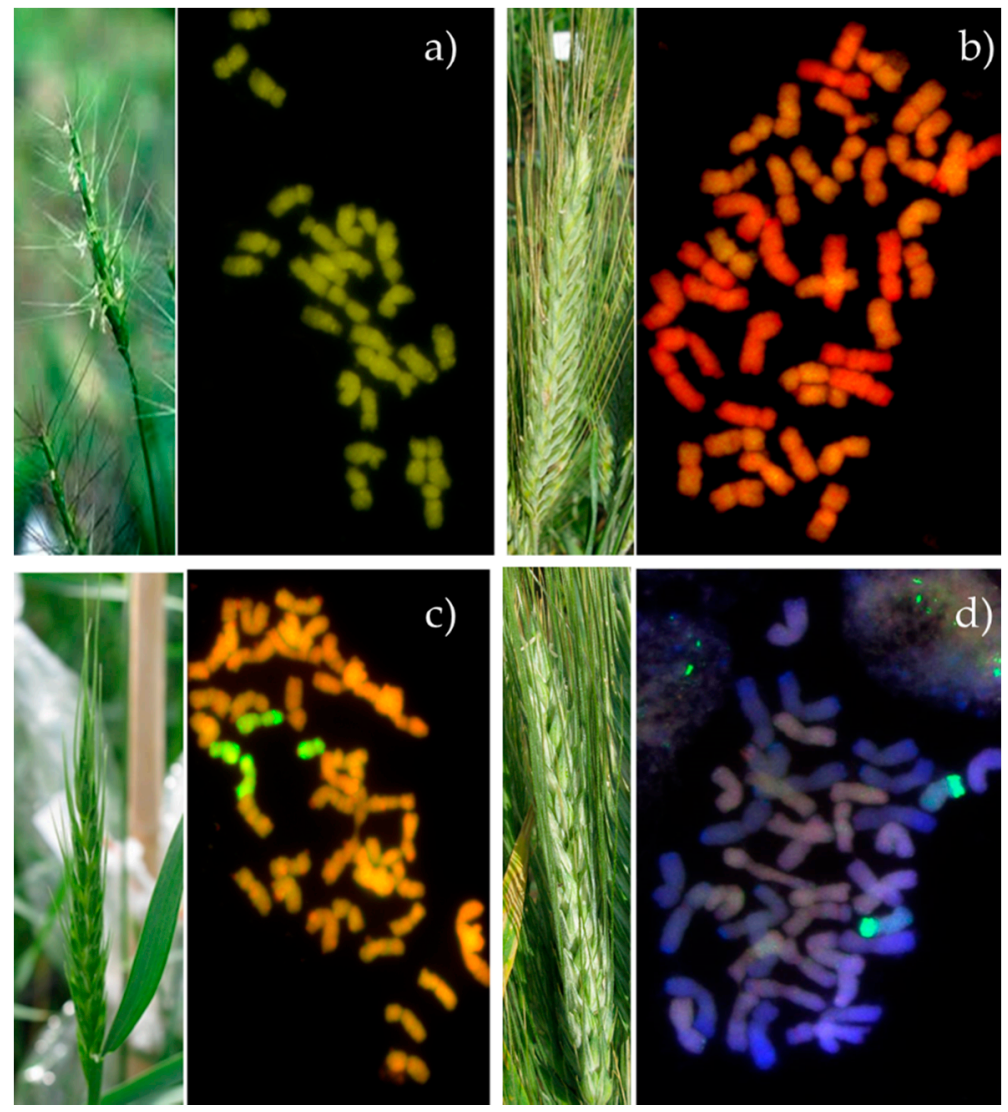

Figure 1. Transfer of alien chromatin segment from (a) Aegilops kotschyi (green) into triticale (b) through subsequent backcrossing, which results in development of (c) addition and (d) translocation lines. On the left—pictures of spikes; on the right—karyotypes revealed by genomic in situ hybridization.

The next step was to develop addition, substitution and translocation lines carrying desirable gene or group of genes associated only with the minimal amount of chromatin [7,35]. Ae tauschii is a rich source of leaf rust resistance genes. Kwiatek et al. [31] have used Aegilops tauschii $\times$ Secale cereale (DDRR, $2 n=4 x=28$ ) amphiploid forms as a bridge between wild and cultivated forms to develop two monosomic addition lines of triticale cv Bogo carrying 2D (with Lr22a and Lr39) and 3D (with Lr32) chromosomes. Both genes were already utilized for improvement of wheat leaf rust resistance. $L r 22 a$ is an adult plant resistance gene, which was introgressed from Aegilops tauschii [36]. Lr39 gene was also transferred into wheat (cultivar Wichita) from Aegilops tauschii accession TA 1675 [37]. Furthermore, Majka et al. [33] analyzed the leaf rust resistance of monosomic $2 \mathrm{D}^{t}$ addition lines of $\mathrm{cv}$. Bogo genotypes at the macroscopic and microscopic level at the seedling. A board spectrum of P. triticiana was used including isolates virulent to both $L r 22 a$ and Lr39 genes. The results showed, that hybrid plants revealed a moderate level of leaf rust resistance at the seedling stage. It was also reported, that triticale $\mathrm{cv}$. Bogo is already very resistant and the introgression of complete $2 \mathrm{D}^{\mathrm{t}}$ chromosome with Lr39 gene showed no additional effect. Following observations showed increasing resistance level at later stages of plant development. This indicates that monosomic $2 \mathrm{D}^{\mathrm{t}}$ addition plants exhibited APR resistance conferred by Lr22a introgressed from Ae. tauschii. Moreover, Majka et al. [33] used this material to produce 26 doubled haploid lines with doubled additional chromosomes 2D of Ae. tauschii, which can be used for further breeding to increase leaf rust resistance of cultivated triticale. Moreover, Kwiatek et al. (in press) developed translocation lines of triticale cv. Bogo with Lr39 locus; however, leaf rust resistance was similar to cv. Bogo.

In another study, Kwiatek et al. [34] obtained monosomic addition and monosomic substitution lines of the triticale carrying $2 S^{\mathrm{k}}$ chromosome from Aegilops kotchyi Boiss., which harbors Lr54 + Yr37 leaf and stripe rust resistant gene loci, respectively. These genes were discovered and transferred into 
wheat [38]. Marais et al. [38] mapped the translocation of Ae. kotschyi chromosome segment to wheat chromosome arm 2DL and reported an improvement of resistance against to eight $P$. triticina pathotypes and two P. striiformis pathotypes endemic to South Africa. Kwiatek et al. [36] analyzed five subsequent backcrossing generations and showed that $2 S^{k}$ chromosome was preferentially transmitted, which allowed to develop a monosomic $2 S^{k}$ addition (MA2Sk) line of triticale cv. Sekundo. Moreover, $2 S^{k}(2 R)$ substitution plants were obtained by crossing MA2Sk with the nullisomic (N2R) plants of triticale. Disease evaluation for the reaction to leaf and stripe rust infection showed significant improvement of leaf rust resistance severity of monosomic substitution plants compared to control ("Sekundo"). In contrast, the introgression of the $L r 54+Y r 37$ loci did not lead to improvement of stripe rust resistance. Ulaszewski et al. [32] crossed monosomic $2 \mathrm{~S}^{\mathrm{k}}(2 \mathrm{R})$ plants with ditelosomic lines of triticale carrying long and short arms of $2 \mathrm{R}$ ( $2 \mathrm{RS}$ and $2 \mathrm{RL}$ ) chromosome separately. The efficiency of production of ditelosomic lines of triticale with chromosome $2 \mathrm{~S}^{\mathrm{k}}$ of Ae. kotschyi carrying leaf and stripe rust resistance genes was at the level of $7.21 \%$. Then, obtained outcross was self-pollinated. Among 100 plants $13 \%$ of $2 S^{\mathrm{k}}$ univalents have been broken in the centromeres at first anaphase of meiosis into long and short arms. In $11 \%$ of analyzed plants observed both $2 S^{\mathrm{k}} S .2 \mathrm{RL}$ and $2 \mathrm{RS} .2 \mathrm{~S}^{\mathrm{k}} \mathrm{L}$ Robertsonian translocation (RobTs) which is a fusion of arms from different genomes during the interkinesis of the second meiotic division of self-pollinated outcross [32]. The inoculation tests in growing chambers showed significant improvement of leaf resistance for translocation lines, comparing to cv. Sekundo (Kwiatek-in press).

\section{Conclusions}

Distant crosses are very laborious and time consuming but only non-GM breeding techniques aimed for introduction of alien chromatin into a donor crop. Above-described studies showed, that secondary genepool of wheat could be successfully introduced into genome of triticale. Addition, substitution, and translocation lines of triticale are unique genetic stocks and can be used as a pre-breeding material for development of leaf and stripe resistant varieties. This type of pre-breeding research is extremely important considering homogeneity of triticale varieties, which reflects greater susceptibility for pathogens, recently. Genetic uniformity of triticale may be increasing on a global scale because of the widespread adoption of modern varieties with similar genetic backgrounds across continents. Moreover, susceptibility to environmental stresses, including diseases can have a real impact on the food supply and regional economy. Hence, utilization of wild species is one of the ways of decreasing crop susceptibility to natural stresses.

Author Contributions: Conceptualization, W.U.; formal analysis, W.U.; writing-original draft preparation, W.U. and M.T.K.; writing—review and editing, W.U. and M.T.K.; supervision, M.T.K.; project administration, M.T.K.; funding acquisition, M.T.K. All authors have read and agreed to the published version of the manuscript.

Funding: This research and the APC were funded by NATIONAL CENTRE FOR RESEARCH AND DEVELOPMENT, Poland (Narodowe Centrum Badań i Rozwoju, Polska), grant number LIDER/3/0004/L-8/16/NCBR/2017, PI—Michał Tomasz Kwiatek.

Acknowledgments: We would like to acknowledge the administrative support provided by the Institute of Plant Genetics of the Polish Academy of Sciences.

Conflicts of Interest: The authors declare no conflict of interest.

\section{References}

1. OECD/FAO. OECD-FAO Agricultural Outlook 2018-2027; OECD/FAO: Rome, Italy, 2018; ISBN 978-92-64-06203-0.

2. Arseniuk, E. Triticale Abiotic Stresses-An Overview. In Triticale; Eudes, F., Ed.; Springer International Publishing: Cham, Switzerland, 2015; pp. 69-81, ISBN 978-3-319-22551-7.

3. Ayalew, H.; Kumssa, T.T.; Butler, T.J.; Ma, X.-F. Triticale Improvement for Forage and Cover Crop Uses in the Southern Great Plains of the United States. Front. Plant Sci. 2018, 9, 1130. [CrossRef] [PubMed]

4. Woś, H.; Brzeziński, W. Triticale for Food-The Quality Driver. In Triticale; Eudes, F., Ed.; Springer International Publishing: Cham, Switzerland, 2015; pp. 213-232, ISBN 978-3-319-22551-7. 
5. Glatthar, J.; Heinisch, J.J.; Senn, T. The Use of Unmalted Triticale in Brewing and its Effect on Wort and Beer Quality. J. Am. Soc. Brew. Chem. 2003, 61, 182-190. [CrossRef]

6. Klikocka, H.; Kasztelan, A.; Zakrzewska, A.; Wyłupek, T.; Szostak, B.; Skwaryło-Bednarz, B. The Energy Efficiency of the Production and Conversion of Spring Triticale Grain into Bioethanol. Agronomy 2019, 9, 423. [CrossRef]

7. Kwiatek, M.T.; Nawracała, J. Chromosome manipulations for progress of triticale $(\times$ Triticosecale $)$ breeding. Plant Breed. 2018, 137, 823-831. [CrossRef]

8. Mergoum, M.; Gómez-Macpherson, H. Triticale improvement and production. In FAO Plant Production and Protection Papers; Food and Agriculture Organization of the United Nations: Rome, Italy, 2004; p. 179.

9. Kiss, A. Kreuzungsversuche mit Triticale [Crossing experiments with Triticale]. Züchter Genet. Breed. Res. 1966, 36, 249-255. [CrossRef]

10. Larter, E.N.; Shebeski, L.H.; McGinnis, R.C.; Evans, L.E.; Kultsikes, P.J. Rosner, a hexaploid triticale cultivar. Can. J. Plant Sci. 1970, 50, 122-124. [CrossRef]

11. Niedziela, A.; Orłowska, R.; Machczyńska, J.; Bednarek, P.T. The genetic diversity of triticale genotypes involved in Polish breeding programs. Springerplus 2016, 5, 355. [CrossRef]

12. Arseniuk, E. Triticale Diseases-A Review. In Triticale: Today and Tomorrow; Springer Science \& Business Media: Cham, Switzerland, 1996; pp. 499-525, ISBN 978-94-010-6634-1.

13. Kolmer, J.A. Wheat Rusts. In Encyclopedia of Plant and Crop Science; Goodman, R.M., Ed.; Routledge: Abingdon, UK, 2004.

14. Lorrain, C.; dos Santos, K.C.G.; Germain, H.; Hecker, A.; Duplessis, S. Advances in understanding obligate biotrophy in rust fungi. New Phytol. 2019, 222, 1190-1206. [CrossRef]

15. Prasad, P.; Savadi, S.; Bhardwaj, S.C.; Gupta, P.K. The progress of leaf rust research in wheat. Fungal Biol. 2020, 124, 537-550. [CrossRef]

16. Schwessinger, B.; Chen, Y.J.; Tien, R.; Vogt, J.K.; Sperschneider, J.; Nagar, R.; McMullan, M.; Sicheritz-Ponten, T.; Sørensen, C.K.; Hovmøller, M.S.; et al. Distinct Life Histories Impact Dikaryotic Genome Evolution in the Rust Fungus Puccinia striiformis Causing Stripe Rust in Wheat. Genome Biol. Evol. 2020, 12, 597-617. [CrossRef]

17. McIntosh, R.; Dubcovsky, J.; Rogers, W.J.; Morris, C.; Xia, X.C. Catalogue of Gene Symbols for Wheat. Available online: https://shigen.nig.ac.jp/wheat/komugi/genes/symbolClassList.jsp (accessed on 10 October 2020).

18. Gill, B.S.; Friebe, B.R.; White, F.F. Alien introgressions represent a rich source of genes for crop improvement. Proc. Natl. Acad. Sci. USA 2011, 108, 7657-7658. [CrossRef] [PubMed]

19. Swiecicka, M.; Dmochowska-Boguta, M.; Orczyk, W.; Gradzielewska, A.; Stochmal, A.; Kowalczyk, M.; Bolibok, L.; Rakoczy-Trojanowska, M. Changes in benzoxazinoid contents and the expression of the associated genes in rye (Secale cereale L.) due to brown rust and the inoculation procedure. PLOS ONE 2020, 15, e0233807. [CrossRef] [PubMed]

20. Park, R.F.; Wellings, C.R. Somatic hybridization in the uredinales. Annu. Rev. Phytopathol. 2012, 50, $219-239$. [CrossRef] [PubMed]

21. Bai, D.; Knott, D. Suppression of rust resistance in bread wheat (Triticum aestivum L.) by D-genome chromosomes. Genome 2011, 35, 276-282. [CrossRef]

22. Rodriguez-Algaba, J.; Sørensen, C.K.; Labouriau, R.; Justesen, A.F.; Hovmøller, M.S. Susceptibility of Winter Wheat and Triticale to Yellow Rust Influenced by Complex Interactions between Vernalisation, Temperature, Plant Growth Stage and Pathogen Race. Agronomy 2020, 10, 13. [CrossRef]

23. Li, J.; Dundas, I.; Dong, C.; Li, G.; Trethowan, R.; Yang, Z.; Hoxha, S.; Zhang, P. Identification and characterization of a new stripe rust resistance gene $Y r 83$ on rye chromosome 6R in wheat. Theor. Appl. Genet. 2020, 133, 1095-1107. [CrossRef]

24. Wellings, C. Global status of stripe rust. In Proceedings of the BGRI 2010 Technical Workshop Oral Presentations, St Petersburg, Russia, 30-31 May 2010; pp. 34-35.

25. Tyryshkin, L.G.; Kurbanova, P.M.; Kurkiev, K.U.; Sarukhanov, I.G.; Kurkiev, U.K. Effective juvenile resistance to brown rust in hexaploid triticale. Zaščita Karantin Rastenij 2008, 10, 25.

26. Mikhailova, L.A.; Merezhko, A.F.; Funtikova, E.Y. Triticale diversity in leaf rust resistance. Russ. Agric. Sci. 2009, 35, 320-323. [CrossRef]

27. Manninger, K. Physiological Specialization of Puccinia triticina on Wheat and Triticale in Hungary in 2004. Acta Phytopathol. Entomol. Hung. 2006, 41, 93-100. [CrossRef] 
28. Czajkowski, G.; Karska, K.; Strzembicka, A. Characteristic of winter triticale breeding lines in term of the degree of infestation by Puccionia triticiana and Blumeria graminis. Biul. Inst. Hod. Aklim. Roślin 2013, 268, 59-67.

29. Grzesik, H.; Strzembicka, A. Resistance of some winter triticale varieties to leaf rust (Puccinia recondita f. sp. tritici). Biul. Inst. Hod. Aklim. Roślin 2003, 230, 171-175.

30. Grzesik, H.; Strzembicka, A. Studies on inheritance of the resistance to leaf rust (Puccinia recondita f.sp. tritici) of winter triticale varieties at the seedling and adult plant stages. Plant Breed. Seed Sci. 1999, 43, 85-89.

31. Kwiatek, M.; Majka, M.; Wiśniewska, H.; Apolinarska, B.; Belter, J. Effective transfer of chromosomes carrying leaf rust resistance genes from Aegilops tauschii Coss. into hexaploid triticale (X Triticosecale Witt.) using Ae. tauschii $\times$ Secale cereale amphiploid forms. J. Appl. Genet. 2015, 56, 163-168. [CrossRef] [PubMed]

32. Ulaszewski, W.; Belter, J.; Wiśniewska, H.; Szymczak, J.; Skowrońska, R.; Phillips, D.; Kwiatek, M. Recovery of 2R.2Sk Triticale-Aegilops kotschyi Robertsonian Chromosome Translocations. Agronomy 2019, 9, 646. [CrossRef]

33. Majka, M.; Serfling, A.; Czembor, P.; Ślusarkiewicz-Jarzina, A.; Kwiatek, M.T.; Ordon, F.; Wiśniewska, H. Resistance of (Aegilops tauschii $\times$ Secale cereale) $\times$ Triticosecale Hybrids to Leaf Rust (Puccinia triticina) Determined on the Macroscopic and Microscopic Level. Front. Plant Sci. 2018, 9, 1418. [CrossRef]

34. Kwiatek, M.T.; Wiśniewska, H.; Belter, J.; Ulaszewski, W.; Phillips, D. Development and cytomolecular identification of monosomic alien addition and substitution of $2 S^{\mathrm{k}}$ chromosome from Aegilops kotschyi to triticale ( $\times$ Triticosecale Wittmack). Front. Plant Sci. 2020. [CrossRef]

35. Kwiatek, M.T.; Kurasiak-Popowska, D.; Mikołajczyk, S.; Niemann, J.; Tomkowiak, A.; Weigt, D.; Nawracała, J. Cytological markers used for identification and transfer of Aegilops spp. chromatin carrying valuable genes into cultivated forms of Triticum. Comp. Cytogenet. 2019, 13, 41-59. [CrossRef]

36. Rowland, G.G.; Kerber, E.R. Telocentric mapping in hexaploid wheat of genes for leaf rust resistance and other characters derived from Aegilops squarrosa. Can. J. Genet. Cytol. 1974, 16, 137-144. [CrossRef]

37. Gill, B.S.; Raupp, W.J.; Browder, L.E.; Cox, T.S. Registration of KS86WGRC02 Leaf Rust Resistant Hard Red Winter Wheat Germplasm. Crop Sci. 1988, 28, 207. [CrossRef]

38. Marais, G.F.; McCallum, B.; Marais, A.S. Leaf rust and stripe rust resistance genes Lr54 and Yr37 transferred to wheat from Aegilops kotschyi. Plant Breed. 2005, 124, 538-541. [CrossRef]

Publisher's Note: MDPI stays neutral with regard to jurisdictional claims in published maps and institutional affiliations.

(C) 2020 by the authors. Licensee MDPI, Basel, Switzerland. This article is an open access article distributed under the terms and conditions of the Creative Commons Attribution (CC BY) license (http://creativecommons.org/licenses/by/4.0/). 